\title{
Assessment of Tourist Perception on Service Quality in the Hospitality Industry in Cross River State
}

\author{
Ukwayi, Joseph. K. (Ph.D) \\ Department of Sociology, University of Calabar, Calabar-Nigeria. \\ Email:ukwayi@yahoo.com
}

Eja, Eja. 1 (Ph.D)

Department Urban and Regional Planning, Cross River University of Technology,Calabar-Nigeria. Email:ejako2007@yahoo.com

Unwanede, Chibuzo. C (M.Sc.)

Department of Sociology, University of Calabar, Calabar-Nigeria.

Email:ukwayi@yahoo.com

Accepted: June 10, 2012 Published: July 17, 2012

Doi:10.5296/jsr.v3i2.2117ＵRL: http://dx.doi.org/10.5296/jsr.v3i2.2117

\begin{abstract}
Quality service has become a serious issue among scholars in the hotel industry. This arises due to the fact that operators of the industry still find it difficult to understand what a tourist needs "are" at a particular time. This paper critically examines tourist perception in the hotel industry, with specific reference to the joint contribution of the various service quality dimensions, variables to tourist satisfaction in the industry. This research adopted the Parasurama, Berry and Zeithan (1988) method in evaluating tourist perception of service quality in the hotel industry. Three hypotheses were test and the result shows that tourist were not satisfied with the service quality provided by the operators of the hotel industry in Calabar. According to Chu (2001) the success of the hotel industry depends on the quality of services provided by the operators of the industry. Therefore, it is very important for the operators of the industry to understand the expectation of the tourist if the industry must strive effectively.
\end{abstract}


Key words: Service quality, tourist, perception, hotel industry, expectation.

\section{Introduction}

Zeithaml (2007) propose a formal definition of tourists perception of service quality as "the degree and direction of discrepancy between tourist service perception and expectations". Service quality is the tourist judgement about the overall excellence or superiority of service. The study of tourist's perception on service quality is a critical strategy for success and survival in today's competitive environment (Fynes and Voss, 2001). In recent times hospitality industry has become a major catalyst for the growth of tourism industry. This industry provide the needed services to various tourist and fun-seeker in given locations especially locations with great tourism potentials. However, with the service industry booming across the world in the $21^{\text {st }}$ century, Calabar has been transformed from a manufacturing economy to a service-oriented one owing to it numerous tourism potentials which has necessitated towards the rapid growth of the hospitality industry in the area (Eja, 2011). To stand out in the hospitality industry in Calabar, good service quality has become the most important issue for competitiveness. Today, everyone recognises the pervasion consequences of quality, at the same time, everyone seems to be having difficulty in grasping its many dimension which has becomes a key issue in the management of hospitality industry. A part from this, there is some misunderstanding in perceiving the service quality between the hospitality industry and tourist in which research has shown that many service industry develop their own perception of what, tourist want, which often differ from what the tourist really want this situation has created a gap between tourist and operators of the industry. This study critical examine the perception of tourist in service quality delivery in the hospitality industry with specific reference to the hotel industry where the operators remain relatively helpless in perceiving what it is that the tourist wants or does not want and what he is ready to accept. Beside, the hotel industry in Calabar has proclaimed themselves as leaders in the service industry but has been lacking in training applied to the actual techniques of service itself. Previous studies have examine the relationship that exist between service quality and tourist values in a global perceptively but none as examine this critical issues with respect to service quality in the hospitality industry in Cross River State and Calabar in particular which is the premise of this work. Therefore, this research seek to discover what services must be offered by the hospitality industry to raise tourists satisfaction and to encourage repeat tourist for perpetual business.

\section{Service Quality}

Parasuraman, Zeithaml and Berry (1985, p.48) propose a formal definition of tourist perception of service quality as "the degree and direction of discrepancy between tourist service perceptions and expectations" Ueltschy et al (2004) define service quality as the tourist's judgement about the overall excellence or superiority of the service. Perceived quality can be defined as the tourist's judgment about an entity's overall excellence or superiority (Zethaml, 1987), or as the result of comparing a tourist's expectations prior to receiving the service with the tourist's experiences with the service (Liljander and Strandviz, 
1993, p.6). Growth and Dye (1999) define perceived value as key variables in the tourist's mind influencing the perceived value of service and the quality of the service. DcMoranville and Bienstock (2003) identify service quality as a measure to assess service performance, diagnose service problems, manage service delivery, and a basis for employee and corporate rewards. Parasuraman et al (1988) developed a multi-item scale for assessing customer perceptions of service quality (SERVUAL). The underlying theory of service quality defined by Parasuraman et al (1985) is criticized as it is not well supported by theoretical and empirical evidence related to the relevance of the expectations performance gap (Carman 1990, Cronin and Taylor 1992). In this study, the service quality scale conations five components: atmospherics, accommodation, convenience, responsiveness and professionalism as presented in table 5 .

According to research done by Parasuraman, A., Berry, L.; and Zeithaml, V.A. (1985, 1988), a key to providing superior service is understanding and responding to a customer's expectations. In which, the tourist expect service companies to do what they are supposed to do. They expect fundamentals, not fanciness; performance, not empty promises. In short, customers are paying good money, and they company should provide good service in exchange. At the point of service creation and delivery, all the resources and knowledge of the provider of the service must come together in exactly the right way to ensure an excellent service encounter for the tourist. It is at this point that the tourist compare their expectations with actual service delivery system performance and ultimately arrive at their perceptions of service quality. According to Collier (1987), by managing these moments of truth well, we can actually manage the tourist; perception of service quality.

Parasunaman, Zeithaml and Berry (1990) suggested that tourist's service expectations have two levels: desired and adequate. The desired service level is the service the tourist hopes to receive. It is a blend of what the tourist believes "can be" and "should be". While the adequate service level is that which the tourist's assessment of what the service "will be", that is, the tourist's "predicated service", both of which can change over time and from one service encounter to the next for the same tourist. The tourist's quantity perception depends in the degree to which quality expectations are confirmed or disconfirmed by experience. Based on Gronroo's perceived service quality model (1982), the quality of a service, as perceived by the tourist, is the result of a comparison between the expectations of the tourist and his real-life experiences. If the experiences exceed the expectations, the perceived service quality is positive. If the experiences do not reach the level of expectations, the perceived quality is low. In detail, conceptually, this confirmation/disconfirmation (gap) concept has an important impact on people's thinking about quality. It implies that quality is not an objective phenomenon that can be engineered beforehand. But with proper preparation prior to the service encounter, good quality may be achieved. We already know that tourist perceive quality in a subjective manner. Depending on the level of quality, as measured in some objective sense, will be perceived as good quality for one person may be less acceptable for another. If expectations are raised too high- owing to an advertising campaign for example - the quality of a given service may be disappointing, if only because the customers had unrealistic expectations. 


\section{Al Macrothink}

\section{Methodology}

The study was conducted within the confine of Calabar in Cross River State taking into consideration the hospitality industry with specific reference to the hotel industry and guest houses. One hundred hotels were selected of which forty were sampled for this study. Primary and secondary data were used in this research work. Two hundred and fifty copies of questionnaire were administered to tourists in the various hotels in order to assess their perception on service quality in the hotel industry. The sample framework include all the tourist in a few selected two and three star hotels in Calabar, Cross River State. The sampling population was both the foreigners and the locals. However, the SERVQUAL measurement formulated by Parasurama, Berry and Zeitham (1988) was adopted to measure the tourist perceptions of service quality which were further subjected to reliability tests. Three hypotheses were tested in this research which include1: The reputation for service quality does not or influence by the hotel industry in Calabar. This hypothesis, Reputation variables used were factorized as:-

$\mathrm{x}_{1}=$ Atmospheric

$\mathrm{x}_{2}=$ Accommodation

$\mathrm{x}_{3}=$ Convenience

$\mathrm{x}_{4}=$ Responsiveness

$\mathrm{x}_{5}=$ Professionalism while hypothesis 2 state which that: tourist perception of personal service offered does not or influence by service qualities in the hotel. Service quality (SERVQUAL) were measured using Parasuraman, Zeithmal and Berry (1988) dimension which include: tangible, reliability, responsiveness, assurance and empathy and were presented as:

$\mathrm{y}=$ personal service offered

$\mathrm{x}_{1}=$ tangible

$\mathrm{x}_{2}=$ reliability

$\mathrm{x}_{3}=$ responsiveness

$\mathrm{x}_{4}=$ assurance

$\mathrm{x}_{5}=$ empathy

In hypothesis 3 which involve using SERVQUAL dimension's perception dimension by the tourist to evaluate the general service quality in the hotel industry, the analysis of variance (ANOVA) was adopted.

\section{Findings}

\section{Demographic characteristics of tourist}

The demographic characteristics of the tourist presented in table 1 shows that majority of the tourists were male (55.0\%). It was observed in table 1 that about $74 \%$ of the tourists were Nigerians while $29 \%$ were non-Nigerians. Information on the level of education attainment by tourists shows that tourists with degree certificate were on the high side with a value of $47.3 \%$ compared to Diploma $40 \%$, Masters $18 \%$ and tourist with Ph.D certificate were on the least side with a value of $12 \%$. However, table 1 indicate that $57.3 \%$ of the tourists were single while $42.6 \%$ of the tourist were married.

Table 1: Demographic characteristics of tourist in the hotel industry 


\begin{tabular}{|c|c|c|}
\hline Gender & Number & $\begin{array}{l}\text { Percentage } \\
(\%)\end{array}$ \\
\hline Male & 82 & 55.0 \\
\hline Female & 68 & 45.3 \\
\hline Total & 150 & 100 \\
\hline Age & Number & $\begin{array}{l}\text { Percentage } \\
(\%)\end{array}$ \\
\hline$<25$ years & 60 & 4.0 \\
\hline $26-35$ & 52 & 35.0 \\
\hline $36-45$ & 35 & 23.31 \\
\hline $46-55$ & 3 & 2 \\
\hline Total & 150 & 100 \\
\hline Nationality & Number & $\begin{array}{l}\text { Percentage } \\
(\%)\end{array}$ \\
\hline Nigerians & 111 & 74.0 \\
\hline Non-Nigerians & 39 & 29.0 \\
\hline Total & 150 & 100 \\
\hline $\begin{array}{l}\text { Educational } \\
\text { level }\end{array}$ & Number & $\begin{array}{l}\text { Percentage } \\
(\%)\end{array}$ \\
\hline Diploma & 60 & 40 \\
\hline Degree & 71 & 35.0 \\
\hline Masters & 27 & 18.0 \\
\hline Ph.D & 18 & 12.0 \\
\hline Total & 150 & 100 \\
\hline Status & Number & $\begin{array}{l}\text { Percentage } \\
(\%)\end{array}$ \\
\hline Single & 86 & 57.3 \\
\hline Married & 64 & 42.6 \\
\hline Total & 150 & 100 \\
\hline
\end{tabular}

Source: Field survey, 2011

\section{Tourist expectation}

The tourist expectation in the hotel industry ranged from choice of hotel, hotel rating and feedback as presented in table 2. It was noticed in table 2 that tourist choice of hotel was highly influence by tourist past experiences with a value of $41.3 \%$ followed by convenience with a value of $32 \%$. Table 2 indicate that $27.2 . \%$ of tourists reasons for choosing a particular hotel was influence by suggestions from friends while on the overall rate 66.7 of the tourists claimed the hotel to be good, $18.7 \%$ were on the average and $14.7 \%$ claimed that the hotel to be excellent. On the bases of come back in the future, $78.6 \%$ of the tourists accept to visit back, $13.3 \%$ do not accept while $8 \%$ of the tourists undecided whether to come back in the future or not.

Table 2: Tourist expectation in the hotel industry 


\begin{tabular}{|l|l|l|}
\hline $\begin{array}{l}\text { Choice of } \\
\text { hotel }\end{array}$ & Frequency & Percentage \% \\
\hline Past experience & 62 & 433 \\
\hline Convenience & 48 & 32.0 \\
\hline $\begin{array}{l}\text { Suggestions } \\
\text { from friends }\end{array}$ & 28 & 22.2 \\
\hline Unintentional & 12 & 9.5 \\
\hline Total & 150 & 100 \\
\hline $\begin{array}{l}\text { Overall } \\
\text { rating }\end{array}$ & Frequency & Percentage \% \\
\hline Average & 28 & 18.7 \\
\hline Good & 100 & 66.7 \\
\hline Excellent & 22 & 14.7 \\
\hline Total & 150 & 100 \\
\hline $\begin{array}{l}\text { Come back in } \\
\text { the future }\end{array}$ & Frequency & Percentage \% \\
\hline Yes & 118 & 78.6 \\
\hline No & 20 & 13.3 \\
\hline Undecided & 121 & 8.0 \\
\hline Total & 150 & 100 \\
\hline
\end{tabular}

Source: Field survey, 2011

\section{Result analysis}

The result on the analysis of tourist perception on the hotel industry, the regression analysis conducted, the following result were obtained: $\mathrm{y}=5.232+1.015 \mathrm{x}_{3}+0.025 \mathrm{x}_{5}+$ $6.265 \mathrm{x}_{4}+0.437 \mathrm{x}_{2}+0.135 \mathrm{x}_{1}$. The addition of the five independent variables correlates very well with the service rendered by the staff $(R=0.521)$. The $R^{2}$ of 0.351 of 0.351 shows that about $35 \%$ of the variation in personal service rendered for above independent variables. However, from the equation which shows thus:

$\mathrm{y}=$ Personal service rendered (PS)

$\mathrm{x}_{1}=$ Assurance $\quad($ SQLASS $)$

$\mathrm{x}_{2}=$ Empathy (SQLEMP)

$\mathrm{x}_{3}=$ Reliability (SQCREL)

$\mathrm{x}_{4}=$ Responsibility (SQCRESP) and

$\mathrm{x}_{5}=$ Tangibility (SQLTGR).

This result shows that at 0.05 level of significance to only $\mathrm{x}_{3}$ (Assurance) was significance with a value of 6.270. The result was further analysed to evaluate the difference in SERVQUAL dimensions perceived to be important by the tourist in assessing overall service quality as presented in table 3. However, it was observed in table 3 that F-value for all dimension, Empathy indicate a high significance of $22.413 \mathrm{~F}$-value at 0.05 level of significance compared to other variables while Reliability and Assurance had the least value of 9.012 and 12.112 respectively. 
Table 3: Differences in service quality perceived to be significant by the tourist in assessing overall service quality

\begin{tabular}{|c|c|c|c|c|}
\hline Dimensions & Source & D.F. & F-ratio & $\begin{array}{l}\text { F } \\
\text { Prob }\end{array}$ \\
\hline \multirow[t]{3}{*}{ Empathy } & $\begin{array}{l}\text { Between } \\
\text { Groups }\end{array}$ & 3 & 22.413 & $0.000^{2}$ \\
\hline & $\begin{array}{l}\text { Within } \\
\text { Groups }\end{array}$ & 131 & & \\
\hline & Total & 135 & & \\
\hline \multirow[t]{3}{*}{ Assurance } & $\begin{array}{l}\text { Between } \\
\text { Groups }\end{array}$ & 4 & 12.112 & $0.000^{2}$ \\
\hline & $\begin{array}{l}\text { Within } \\
\text { Groups }\end{array}$ & 131 & & \\
\hline & Total & 135 & & \\
\hline \multirow[t]{3}{*}{ Reliability } & $\begin{array}{l}\text { Between } \\
\text { Groups }\end{array}$ & 3 & 9.012 & $0.000^{2}$ \\
\hline & $\begin{array}{l}\text { Within } \\
\text { Groups }\end{array}$ & 131 & & \\
\hline & Total & 135 & & \\
\hline \multirow[t]{3}{*}{ Responsiveness } & $\begin{array}{l}\text { Between } \\
\text { Groups }\end{array}$ & 3 & 13.111 & $0.000^{2}$ \\
\hline & $\begin{array}{l}\text { Within } \\
\text { Groups }\end{array}$ & 131 & & \\
\hline & Total & 135 & & \\
\hline \multirow[t]{3}{*}{ Tangibility } & $\begin{array}{l}\text { Between } \\
\text { Groups }\end{array}$ & 3 & 14.212 & $0.000^{2}$ \\
\hline & $\begin{array}{l}\text { Within } \\
\text { Groups }\end{array}$ & 131 & & \\
\hline & Total & 135 & & \\
\hline
\end{tabular}

Source: Data analysis, 2011

The mean perception and expectation of tourist on service quality presented in table 4 indicate that the mean of -0.64 for the service quality measure which shows that on average, tourists perceptions felt short of their expectations. This was evidence in table 4 which the perception's mean values of 6.00 lower in every dimension compared to 6.19 mean values of tourist expectation. 
Table 4: Tourist mean perceptions and expectations on service quality

\begin{tabular}{|l|l|l|l|}
\hline Dimensions & $\begin{array}{l}\text { Perceptions } \\
(\mathrm{P})\end{array}$ & $\begin{array}{l}\text { Expectations } \\
(\mathrm{E})\end{array}$ & $\begin{array}{l}\text { Service } \\
\text { quality } \\
(\mathrm{P}-\mathrm{E})\end{array}$ \\
\hline Tangible & 64 & 5.00 & -6.56 \\
\hline Reliability & 7.10 & 5.99 & -0.75 \\
\hline Responsiveness & 5.23 & 6.00 & -0.63 \\
\hline Assurance & 5.14 & 7.01 & -0.93 \\
\hline Empathy & 6.10 & 6.97 & -0.64 \\
\hline Total & 6.00 & 6.19 & -0.64 \\
\hline
\end{tabular}

Source: Data analysis, 2011

However, the summary of predication of tourist value by service quality presented in table 5 shows that the various component of service quality together explain the service quality in the hotel industry. Table 5 shows hotel decor, privacy of guests, attractive rooms and the appearance of staff as an indicator of atmospherics which helps hotel to deliver service of high quality to tourist.

Accommodation was positively associated with reputation for quality $(\beta=0.104 ; \mathrm{p}<0.05)$. convenience was found to be the most important predictor for reputation for quality with a value of $\beta=0.338, \mathrm{P}<0.001$ ) compared to other valuables.

Table 5: Prediction of tourist value by service quality

\begin{tabular}{|c|c|c|c|c|c|c|}
\hline \multirow{2}{*}{ Service quality } & \multicolumn{2}{|c|}{$\begin{array}{c}\text { Restitution for } \\
\text { quality }\end{array}$} & \multicolumn{2}{c|}{ Value for money } & \multicolumn{2}{c|}{ Prestige } \\
\cline { 2 - 7 } & $\boldsymbol{\beta}$ & $\mathbf{t}$-value & $\boldsymbol{\beta}$ & t-value & $\boldsymbol{\beta}$ & t-value \\
\hline Atmospherics & .273 & 6.55 & .307 & $4.721^{* * *}$ & .386 & $5.091^{* * *}$ \\
\hline Accommodation & .104 & 1.801 & .074 & 1.013 & .254 & $2.488^{* *}$ \\
\hline Convenience & .338 & $18.57 * * *$ & .706 & $15.44 * * *$ & .252 & $3.816^{* * *}$ \\
\hline Responsiveness & -064 & -93.5 & .00 & .002 & .037 & .617 \\
\hline Professionalism & .148 & $2.072 *$ & .096 & .1340 & .081 & .911 \\
\hline R Square & .737 & & 500 & & .408 & \\
\hline $\begin{array}{c}\text { Adjusted R } \\
\text { Square }\end{array}$ & .551 & & $103.827 * * *$ & & $61.755^{* * *}$ & \\
\hline f-Ratio & $141.5 \beta^{* * *}$ & & 29.295 & & 485 & \\
\hline N & 377 & & 295 & & 485 & \\
\hline
\end{tabular}

Source: $\quad$ Data analysis, 2011

\section{Recommendations}

Service quality has become a crucial aspect in the hotel industry which most tourist desire to be enhance in order to create good image to the industry. Perhaps this aspect has 
not been taken into consideration by the operators of this industry (Saleh, 2000). In Cross River State, the issue of service quality has gain little or no recognition in the hotel industry and as a result, the industry suffered a series of setbacks in terms of tourist patronage. To this end, the following measures are recommended in order to redeemed the image of the industry.

$>$ The hotel industry as service providers should focus especially on those factors perceived quality that are most important to tourist

The hotel industry most focus on the level of comfort and convenient offered to tourist, including the flexibility of check-in and check-out times.

Hotel industry should improve communications and relations between management and staff and there is need to focus their efforts on enhancing the intangible aspects of service delivery, such as, interaction between staff and tourist

\section{Conclusion}

Quality service has become a fundamental issue in hotel management in Cross River State; one can draw a conclusion from the results that tourist perceptions in the hotel industry in Cross River State and Calabar in particular fall short of expectation even though some component of the service quality have created little impact to the development of the hotel industry in Calabar. Since tourist will always make decision and taking an action based on their perceptions, there is urgent need for the organization or hotel industry to take an effort in comprehending and understanding tourist's expectation in order to provide good quality services to tourist and other fun-seekers in the area.

\section{REFERENCES}

Eja, E.I. (2011). An assessment of the relevance of Christmas festival in the development of sustainable hospitality industry in Calabar city. African journal of social sciences, vol.1, no.3, pp.1-9.

Eja, E. I. (2011). Using multiple regression in modelling the role of hospitality industry in tourism development in Calabar. African research review, Vol.5,

No.5, pp.156-165.

Eja, E. I. and Otu, J. E. (2011). Impact of hospitality industry in poverty alleviation on a tourist destination. Cross River State Scenario. Mediterranean journal of social sciences. Vol.2, No.3, pp...

Eja, E. I. and Ndoma, B. N. (2011). Tourism as a catalyst for hospitality industry development in Calabar, Nigeria, e-review of tourism research (eRTR), Vol.9, No.1, pp.13-32.

Ekinci, Y. P., Prokopaki, and C. Cobanoglu, (2003). Service quality in Cretan accommodations: Marketing Strategies for UK Holiday Market. International Journal of Hospitality Management. 22, 47-66. 
Fynes, B. and C. Voss (2001). A path analytic model of quality practices, quality performance and business performance. Production and Operation Management . Winter (10), 494-510.

Growth, J. C. and R.T. Dye (1999). Service quality: guidelines for marketers. Managing service quality, 9(5), 337-351.

Imrie, B.C., J.W. Cadogan and R. McNaughton(2002). The service quality construct on a global stage. Managing service quality. 12 (1), 10-18.

Kim, B. Y. (2004). How do hotel firms obtain a competitive advantage. International journal of contemporary hospitality management. 16(10, 65-71.

Mei, A.W. O., A,M. Dean and C.J. White(1999). Analyzing quality in the hospitality industry. Managing service quality. 9(20), 136-143.

O’Neil, M., H. Watson and M. Mckenna (1994). Service quality in the Northern Ireland hospitality industry. Managing service quality, 4(3), 36-40.

Parasuraman, A., V.A. Zeithamlm and L.L. Berry (1985). A conceptual model of service quality and its implication for future research. Journal of Marketing (Fall), 41-50.

Petrick, J.F. (2002). Development of multi-dimensional scale for measuring the perceived value a service. Journal of leisure research, 34(2), 119-134.

Raymond, C. (2001) Determinants of hotel satisfaction and repeat patronage in the Hong Kong hotel industry. International journal hospitality management 20, 277-297

Saleh, F. and C. C. Ryan (1991). Analyzing service quality in the hospitality industry using the SERVQUAL Model. Services Industries Journal, 11(3), 324-343.

Scheneider, B. and B. Chung (1996). Service quality. Trends in organizational behavior, 3, 67-80. 